\title{
THE CONCEPTUALIZATION OF QUALITY OF WORKING LIFE
}

\author{
C. ORPEN ${ }^{*}$ \\ DEPARTMENT OF PSYCHOLOGY \\ UNIVERSITY OF WITWATERSRAND
}

\section{OPSOMMING}

\begin{abstract}
'n Poging word aangewend om die begrip kwaliteit van werkslewe te omlyn. ' $n$ Aantal situasie-gebonde kriteria word voorgestel waarvolgens die kwaliteit van werkslewe in 'n organisasie bepaal kan word. Die kriteria word onder die volgende indelings bespreek: toereikende vergoeding, werktoestande, menseverhoudings, werk en ontspanning, effektiewe prestasie en sosiale verantwoordelikheid. 'n Aantal persoonlike kriteria word ook voorgestel waarvolgens persoonlike welsyn beoordeel kan word. Dit sluit in: kennis, kreatiwiteit, individualisering, harmonie, realiteit en selfverwesenliking. Deurgaans word aandag gevestig op wat die organisasie kan doen om aan bogenoemde kriteria, wat gesamentlik die gehalte van werkslewe omskryf, te voldoen.
\end{abstract}

It has become increasingly apparent that a full appreciation of the extent to which a society or community is effective cannot be obtained by merely examining the extent to which it has achieved certain material goals. And the reason is not hard to find. It is that a society or community cannot be said to be fully effective unless it satisfies not only the material, but also the so-called psychological needs of its members. The trouble, of course, is that whereas it is possible to assess material success in terms of a variety of quantifiable indications such as output per head, gross national product, cement production, number of motor cars, electricity generated and so forth, the psychological quality of a community or society is less easily documented. The present paper deals with an important element of the psychological quality of a society or community, namely the quality of the working lives of its members. More specifically, it attempts to deal with two interrelated issues. First, it deals with the thorny question of what is meant or understood by the phrase 'quality of working life', one that has become so widely employed over the past few years; that is, how the term can best be conceptualized. Second, it concerns itself with the various criteria in terms of

\footnotetext{
${ }^{*}$ Requests for reprints should be sent to the author.
} 
which to measure or assess the quality of the working lives of members of a society or community, and the relation of such criteria to material goals.

At the outset, it should be noted that the questions to be raised in this article are not merely of a factual or empirical nature, but also involve evaluative considerations. This is because attempts to understand what is involved in the improving the quality of working life require an examination not only of what people are and what they do, but also of what people and jobs should and could be like (e.g. Argyris, 1964; Barron, 1963). In addition, underlying the article is a belief or assumption shared by most industrial psychologists; namely, that it is morally desirable for work to be such that people like it, that everybody concerned with the world of work should be taking more active and vigorous steps than at present to make work more likeable for those who have to do it (Dunnette, 1976; Bennis, 1966).

The present analysis has, as its starting point, the observation that work is a central part of life and society and that it is not something that can be made to disappear. As a corollary, it accepts that work is something that matters to people and that it is often of overwhelming importance to them, if for no other reason that they usually spend so much time at it. For these two reasons alone, the task of making work more likeable is a supremely important one, no matter how complex and difficult this may be.

The task of making work more likeable has increasingly been discussed within the points of reference supplied by the phrase or term, quality of working life. Hence, as a first step, it is essential to clarify precisely what it means. Unfortunately, quality of working life has been used with increasing frequency in a vague sort of way to describe a set of unspecified humanistic values which people increasingly feel have been neglected by industrialized communities and societies in their exclusive concern with technological advancement and economic growth as the only really important ends or goals. In spite the vague way in which the term is used, this vagueness does possess the virtue of drawing attention to an important aspect of 'quality of working life'; and that is its comprehensiveness. For instance, the concept embraces, but is much broader than, the aims of the long series of legislative acts passed by most industrialized countries, both capitalist and socialist, to prevent such things as child abuse, excessive working hours, hazardous work conditions and the like.

In addition, the concept clearly covers much more than is traditionally sought by trade unions. Specifically, quality of working life refers to a set of goals which are much wider than those of the trade union movement that has gained so much in strength over the past few decades, such as job security, due process in the work place, and economic gains for the 
worker. Moreover, it is broader than the notion or idea popularized by psychologists in the 1950 's, that high morale leads to greater productivity and that the way to secure the former is through improved human relations. Finally, the concept covers much more than does the various attempts in the 1960's to reform jobs, in the direction of making them more inherently interesting and challenging, and to increase the extent of employee involvement in decisionmaking.

Although the term is wider and broader than the goals of any of these various reform movements, it nevertheless includes the values and aspirations that lie at the heart of each of them (Herzberg, 1966; Jahoda, 1955; Wilson, 1973). Although there is room for debate, these aspirations and values can be rather neatly summed up by saying that each of the reform movements listed in the previous paragraph was essentially concerned with helping to ensure that people would be satisfied with their jobs.

Their values and aspirations were, put simply, to try to improve job satisfaction. The persons behind the legislative acts of the 1920's, the trade union movement that really got off the ground during the depression of the 1930's, and the human relations and job reform approaches of the 1950's and 60's, would each have been more than pleased if their actions had resulted in people being truly satisfied with their working lives.

But quality of working life stands for more than just job satisfaction, at least in three important ways. First, the notion of job satisfaction excludes specific reference to performance. Although there is disagreement over details, job satisfaction is generally defined as the difference between what a person feels he should receive from the work situation and what he feels he actually receives. In terms of this conceptualization, if these two perceptions are in rough agreement a person is said to be satisfied with his job (Katzell, 1964; Locke, 1968; 1969; Lawler, 1971). From the point of view of the concept of quality of working life, the difficulty is that there is no necessary or inevitable relationship between feeling satisfied working one's job in this sense and performing it well. It is by no means always the case that people who feel positively towards their work will perform better than others who may not feel so positively about their work. Although at the extremes of positive and negative feelings there is usually a fairly close relation between these feelings and effective and ineffective performance respectively, generally they are dwarfed by differences in ability, motivation, role perceptions as well as differences in economic and social conditions (cf. Herman, 1973; Wicker, 1969). Since the quality of any individual's working life cannot really be said to be high unless he is not only happy with his job but also does it well (e.g., Bennis, 1966; 
Sofer,1961) the concept of job satisfaction falls short of what is generally understood by 'quality of working life' in at least one important respect.

Second, the notion of job satisfaction is restrictive in that its emphasis is largely a negative one. In practice, studies of satisfaction among different classes of workers have essentially been concerned with the removal of unpleasant features of the environment. Specifically, job satisfaction studies have indicated what should be done to 'get rid' of those features of the work situation that have been shown to be responsible for negative feelings about ones job; with the desirable state being seen as a reduction of dissatisfaction. Although this kind of negative conception of satisfaction is of course partly valid, it omits several important features of what is understood by psychological well-being in the work situation. It is often the case that to promote job satisfaction we have to remedy the environmental deficiencies or reduce the cause of individual complaints (by, for instance, improving lighting and ventilation, or improving tools and equipment, or even dismissing an obnoxious supervisor), but this only goes some of the way towards ensuring that the quality of working life is high. The principal reason for this state of affairs is that feeling good about one's job an essential ingredient of what is understood by quality of working life - is not entirely the same as not feeling bad about it, as Herzberg (1966) and Locke (1976) have so clearly demonstrated.

Third, the notion of job satisfaction that prevails among industrial psychologists fails to capture the element of positive mental health that is a central feature of any conception of quality of working life. As indicated above, in its full sense quality of working life or psychological well-being at work is a question of satisfaction plus something else, the nature of which can be made clear by considering what is involved in being healthy. In one sense we are healthy if we are not ill, and the medical profession is dedicated to our health in this negative sense of curing our illnesses. Less obviously it is also concerned with making healthy people healthier by extending them in various ways, to increase their fitness. The point is that positive health, whether mental or physical, consists of ways of living that go beyond the 'mere existence' implied by the negative ideas of health that are embodied in the orthodox view of job satisfaction. An adequate conception of good mental health or psychological wellbeing refers to something more than such notions as adjustment, contentment or freedom from inner tensions, which are clearly implied in the view that job satisfaction occurs when people merely get what they want from the work situation. A person who wants little from his work may be satisfied if he gets little, but his state cannot be 
described as one of psychological well-being. And the reason is not hard to find. It is that this notion of job satisfaction omits the positive aspects of mental health, the active efforts of people to cope with, and enlarge upon, their world and perhaps even to make it more like they want it to be. The point is that a working life of high quality is one in which an individual experiences feelings of psychological well-being, and that this requires not only an adjustment to the work environment so that negative states are minimized but also the occurrence of what has been called 'psychological growth'. It is the omission of this factor, perhaps more than any other, which explains why job satisfaction is such an inadequate yardstick of the quality of working life (Locke, 1976; Wilson, 1973).

\section{CRITERIA OF THE QUALITY OF WORKING LIFE}

An examination of what is involved in 'psychological growth', of what it is that distinguishes this condition from others, leads us on to a consideration of the so-called criteria of the quality of working life. In effect, what we are proposing is a set of yardsticks against which to assess the quality of working life. On the basis of what has been said before, it should be clear that these criteria must both include those that have been set down by each of the previous reform movements as well as the more recent ones that are concerned with job satisfaction-plus, namely effective performance, mental health, and psychological growth. We shall start with the former and then move onto a consideration of the latter, paying special attention to the most widely-accepted analyses of mental health and psychological growth particularly those by Jahoda (1955) and Herzberg (1966).

\section{Criteria of quality: Situational aspects}

\section{Adequate compensation}

Although accepted operational definitions are not available to judge the fairness of work compensation, and the extent to which it is sufficient to meet the important needs of individuals, both these factors of fairness and sufficiency are important determinants of the quality of working life. It is only a small, if not negligible, proportion of people who can experience anything like a state of psychological well-being, without being adequately compensated for their work. Perhaps to a greater extent than any of the other criteria that will be proposed, adequacy of compensation is a relative concept that cannot be defined properly without a detailed knowledge of the work situation and the particular individual, especially his past history as regards compensation. 
There simply is no consensus on the various standards against which to judge adequacy of compensation in general terms. However, fairness in compensation can at least be defined operationally even if there is often disagreement as to what constitutes fair or unfair compensation. Without going into details, there are at least four ways of going some way towards establishing fairness of compensation. For instance, job evaluation procedures specify relations between pay and factors such as training required, job responsibility, complexity of decision-making, and unpleasantness of working conditions. In addition, a number of techniques are available to determine the supply and demand for particular categories of manpower and for establishing community averages for such categories, thus helping to determine fair levels of compensation. Finally, yardsticks are available to establish what proportions of profits are usually paid to employees in different job categories and how these proportions differ across different kinds of jobs and levels of efficiency.

Although it is possible to specify standards of fairness in these ways, two major problems still remain. First, the fairness of pay is partly determined by ideological issues as to what should be the difference in the average pay of people doing different jobs (Lawler, 1971). Second, quite often a pattern of compensation is judged to be fair by one set of criteria but unfair by another (Opsahl \& Dunnette, 1966).

\section{Working conditions}

Largely as a result of the effectiveness of the reform movements of the 1920's and 1930 's, it is widely accepted in contemporary society that employees should not be exposed to work conditions that are unduly hazardous or detrimental to their health.

In fact, as a result of trade union pressure and changes in societal norms and values, today most people agree that it is the responsibility of management to ensure that work conditions actually promote the psychological well-being of workers. Because of union action, legislation, and employer concern, there have been marked improvements over the past few decades in such aspects of the work environment as work hours, safety regulations, noise, illumination, work space, and accident prevention. Increasingly, the concern has shifted from preventing physical injury and illness, to one of promoting comfort and ease in the work situation. The trouble of course with both compensation and working conditions is that, while in themselves they are very capable of removing feelings of job dissatisfaction, they are seldom able to arouse strong feelings of satisfaction (e.g. Kornhauser, 1965; Lofquist \& Davis, 1969; Wall, 1971). For most, but clearly not all, employees in contemporary western 
society, fair compensation and good working conditions function mainly as 'hygiene factors' to adopt Herzberg et al's (1959) terminology - in that we are unhappy in the work situation without them, but increasing them beyond a certain level does not make us positively more healthy.

This is an important point, for it demonstrates that even if compensation and working conditions are excellent, we may still have a long way to go before the situation is such that we can speak of it as leading to the psychological well-being of employees. For instance, despite working conditions that are excellent and pay that is very good, employees may feel that their needs for personal growth cannot be properly gratified in the work situation.

Because they regard their work as restrictive and stultifying their experience in the job may be the opposite of those characterized by the phrase, psychological well-being. Moreover, even if they felt that these needs could be met, employees may lack the necessary ability and job knowledge to really perform effectively and may suffer feelings of inadequacy as a result, neither of which are conductive to a state of psychological well-being. Hence, while the provision of excellent working conditions may be necessary for a high quality of working life, it is clearly insufficient by itself.

\section{Human relations}

As psychologists in the 1950's made so evident, what is missing from the above two factors is the so-called 'human relations' element. Starting with the Hawthorne studies in the 1940 's, they convincingly demonstrated that poor or inadequate relations among employees and between them and their superiors may nullify or destroy any 'positive' impact that would normally be expected from adequate compensation and excellent working conditions. In their concern with such things as pay, work hours, illumination, noise, temperature and the like, the early industrial psychologists often lost sight of the fact that a work organization is itself a system of social groups with overlapping membership and that these groups have their own objectives beyond those formally established by the organization leaders (Likert, 1951; Vroom, 1964).

The importance of this point becomes clear, in the most immediate way, when one considers the variety of satisfactions and dissatisfactions that have their origin in the interpersonal relations people inevitably form at work. The variety of contacts that an individual develops at work with others helps in many cases to satisfy one of man's most basic and fundamental needs, that of social belongingness. In addition, it is through interpersonal 
relations that employees help to overcome the existentialist aloneness of each individual, to which many writers have drawn attention (e.g., May, 1967; Maslow, 1959; Hampden-Turner, 1971). Moreover, work groups allow people an easy and effective way of comparing their abilities and opinions with others, a process that Festinger (1954) contends is necessary if individual are to remain in proper context with reality. Finally, work groups inevitably develop norms and values regarding the appropriate, way to think and behave in different jobrelated situations. Such values and norms assist individuals to structure and organize their social world and help to give them some socially validated understanding of themselves and the people with whom they interact. Because interpersonal relations have such deep and pervasive effects on individuals it stands to reason that they represent an important class of variables for psychological well-being. Although more research is needed into the different kinds of needs that are gratified through relations with others, there can be little doubt that people who have 'good' relations with others at work are likely to experience a greater sense of well-being in the work situation than their counterparts, whose relations with others are inadequate in important respects.

In brief, it is argued that whether an individual's relation with others enhances his personal growth or not, depends to a larger extent on whether those relations are characterized by the following:

- Supportiveness: Membership of face-to-face groups at work in which relations between the individual and others are marked by socio-emotional help, respect for the individuality of each member, a high degree of reciprocity or mutual help, and an openness and frankness in dealing with interpersonal problems that may arise.

- Tolerance: An acceptance of each member on equal terms with every other member, without regard to such factors as racial origin, religion, socio-economic background, or even physical appearance, which seldom have an overriding effect on the individual's capacity to contribute to group goals or tasks.

- Equality: The existence of work groups which are characterized by flat or horizontal, rather than steep, internal status hierarchies, and in which rankings are based largely on member contributions to group goals, whether those be task-oriented or essentially concerned with keeping the group together in a harmonious way.

- Mobility: Primary or face-to-face groups in which the various members are encouraged to aim for positions within the firm higher than those held by most group members, 
even at the expense of the particular members perhaps leaving the group, and ceasing to be a full member.

- Identification: A quality in the relations between members of a face-to-face group which encourages members to feel that they belong to the group in a most direct and personal way; where they feel that the group is their group, while still feeling that they are separate from the group in terms of their own uniqueness as an individual.

In the light of these factors, it stands to reason that work organizations which are concerned with quality of working life should do everything in their power to ensure that the work groups that constitute their organizations are characterized by high degrees of supportiveness, tolerance, equality, mobility, and identification.

\section{Opportunity for personal growth}

There are two aspects to this important prerequisite for a high quality of working life. The first is concerned with the nature of the jobs people actually have to do on a day-to-day basis. The second deals with the formal opportunities that are provided for people to advance beyond their present jobs to ones that challenge and stretch their capacities more than their present jobs may do.

As regards the first point, there can be little doubt that much of the meaning has been taken out of work by the deliberate process of specialization that started as far back as the industrial revolution in the 1800 's. In order to improve efficiency and reduce costs, from this time jobs have been progressively deskilled, fractionated and highly controlled. However, today workers are increasingly rebelling against doing these sorts of repetitive and monotonous jobs (Walker \& Guest, 1962; Shephard, 1969). In addition, managers are increasingly starting to appreciate that those kinds of jobs often retard and stultify personal growth, and in this way often lead to a deterioration rather than an improvement in the quality of working life (Davis 1967; Wilson, 1973). In spite of the limitations of most research concerned with the effects of job redesign on employee satisfaction and productivity, we are still left with the fact that most of the studies indicate that people not only prefer jobs which offer them variety, feedback, independence and distinction, but that such jobs also lead to enhanced well-being, as well as better mental health (compare Paul \& Robertson, 1970; Birchall \& Wild, 1973). Furthermore, the evidence shows that even extremely repetitive and simple jobs, which most people find monotonous, can be redesigned so as to be more inherently interesting and challenging to those who have to perform them. Although there are 
difficulties, often serious ones, that need to be overcome, work organizations must ensure that most of the jobs that have to be done are of such a nature that they will stretch and develop the capacities of those who have to do them, rather than the opposite. This is an important point, for only if the various jobs in a work organization are capable of having this kind of effect, is there any chance of a work organization being able to secure a high quality of working life for its members.

Among the most important features which jobs must possess if they are to lead to positive personal growth on the part of incumbents are the following:

- $\quad$ Autonomy: The work should be designed in such a way as to permit the incumbent substantial independence and self-control, in terms of what he has to do and how he goes about doing it.

- Skill variety: The job should give the incumbent the opportunity to exercise a wide range of his capacities and abilities, rather than merely require him to repeat a single narrow skill or a few specialized aptitudes.

- Task significance: The individual should be encouraged to ask for, and be given, detailed and complete information about all aspects of his job and how it fits into the total work organization. In this way he can come to appreciate the significance of his job and the relevance and consequences of different actions he may take.

- $\quad$ Feedback: The various duties and tasks that are required of an individual should be such that he can be given full and accurate knowledge regarding his performance and its effects elsewhere in the organization. Moreover much information should be supplied to him as quickly as possible whenever it is felt that it will improve his performance and satisfaction.

- Meaningfulness: The duties and tasks that define a particular job should make sense to the person who has to perform them, in that he feels that doing them well or poorly will make a difference to himself and to others in the work organization.

- Wholeness: The job should embrace a set of tasks and duties that 'go together' in a meaningful way and are different in important ways from the duties and tasks of jobs done by other people in the organization. 
As regards advancement, there can be little doubt that the wellbeing of employees requires not only that their actual jobs are designed along the lines indicated above, but also that they are given ample opportunity for self-improvement through promotion to more challenging and responsible jobs and through further education of one sort or another. There are four interrelated aspects to this problem each of which needs to be satisfactorily solved, before it is possible to speak of a high quality of working life.

- Development: The degree to which a person's current activities, especially the duties and tasks that are his present job, contribute to maintaining and expanding his capabilities and interests, rather than leading to obsolescence or a narrowing of horizons.

- Advancement: The extent to which an individual can legitimately expect to make greater and wider use of his various skills and talents in future work assignments.

- $\quad$ Recognition: The degree to which formal opportunities are given to persons to advance into positions or jobs which, in organizational or career terms, are recognized by peers, associates or family members.

- $\quad$ Safety: As a negative corollary to these three forward-looking aspects; individuals should not feel that they are in unreasonable danger of losing their jobs or having their compensation reduced, unless it is due to factors completely beyond the control of organizational leaders.

\section{Rights in the work organization}

Besides the above criteria that help to define what constitutes quality of working life, there are another set that are frequently overlooked by industrial psychologists, since they are essentially of a legal nature, and are concerned not so much with how people behave but rather with what rights they should enjoy whether they exercise them or not. The criteria to be proposed are essentially concerned with the extent to which work organizations, acting either in response to trade union pressure or on their own initiatives, have set up formal procedures to protect the individual worker from arbitrary and capricious actions by employers. According to a number of authorities (e.g. Bell, 1974; Friedman, 1961; Hill, 1971) only if the work organization ensures that the following so-called 'rights of individuals' are officially respected can the quality of working life be high. 
- $\quad$ Privacy: The right of individuals to personal privacy. The fact they are entitled to expect that things they consider part of their private lives are not divulged to others without their permission.

- Equity: The right of individuals to equitable treatment in all matters of importance on the job, such as compensation, status, security and advancement. The fact that they are entitled to expect that they will be given fair treatment by the organizational leaders and will not be at a disadvantage compared to others, because of factors irrelevant to job performance.

- $\quad$ Free speech: The right of individuals to disagree openly with the ideas and opinions of their superiors in the organization without fear of reprisal or subsequent victimization. The fact that they should feel free to indicate their views and opinions about job-related issues without having to worry that these opinions and views will be used against them if they do not happen to be shared by their superiors.

- Due process: The right of individuals to be governed by the 'rule of law' rather than by the arbitrary and capricious actions of particular individuals, with established procedures to prevent them suffering unfairly at the hands of others. The fact that all people in the organization, from the lowest to the highest level, should have the same access to appeals and to due process procedures.

- $\quad$ Equality: The right of individuals not to be penalized because of their membership of any particular group or class. The fact that all individuals are entitled to expect to be treated in the same way as others, irrespective of their sex, race, religion, or social class.

\section{Work and leisure}

There is a wealth of evidence which points to the fact that an individual's work experiences can have positive or negative effects on his non-working life, such as how he spends his leisure and what sort of relations he has with family members (e.g. Safer, 1970; Salaman, 1974). The importance of this point for the concept of quality of life is that work organisations, by virtue of this kind of 'spill-over' effect, influence an individual's life of-thejob.

As a number of investigators (Jahoda, 1955; Herzberg, 1966; Argyris, 1964) have suggested, a high quality of life requires that individuals achieve some state of balance or harmony between their working and non-working lives. On the one hand, for optimum well- 
being their lives should not be dominated by their work, to the extent that the quality of their lives off-the-job is seriously impaired. On the other, their non-working lives should not be of such a nature that it impairs or depresses the quality of their working lives. It is because of this two-way process, from work to non-work and in the opposite direction, that this particular criterion of quality of working life is difficult to apply. For instance, to take a very common example, when a person invests virtually all his energy, and most of his working time in his particular job or occupation at the expense of his family, it is by no means clear whether this is a cause or symptom of deficiencies in his family relations. In some cases, the work organization is at fault in making demands on the person that seriously limit or impair his ability to perform his non-work roles properly. In other cases, the fact that a person's work absorbs so much of his time and energy may be the results of an unhappy family situation, which is largely of his own making.

\section{Performance}

Although we have shown that the notion of job satisfaction does not include everything that is normally understood by quality of working life, it is odd, to say the least, to speak of someone having a high quality of working life but to be dissatisfied with his job. The reason for this is that, whereas a high degree of job satisfaction is not a sufficient condition for the quality of working life to be high, it is clearly a necessary one. This implies that those factors that are necessary for high levels of job satisfaction must also be present if the quality of working life of the particular individual is to be high.

Research has shown that probably the most important determinant of job satisfaction, although clearly not the only one, is effective performance (Locke, 1976; Porter \& Lawler, 1968). Specifically, it has demonstrated that under a number of conditions, individuals who perform effectively are likely to be much more satisfied with their jobs than those who perform less effectively, and hence tend to experience a greater sense of well-being at work than the latter. Since psychological well-being is roughly equivalent to many conceptions of quality of working life, this means that, other things being equal, people who perform well can usually be regarded as having a higher quality of working life than those who perform poorly. The extent to which this kind of relationship between performance and satisfaction is found depends on a number of conditions, such as the possession of requisite abilities on the part of incumbents (Carlson, 1969; Orpen, 1976), a strong link or relation between reward and performance (Porter \& Lawler, 1968), the absence of situational constraints that make the 
translation of effort into performance difficult to achieve (Lawler, 1971) and accurate role perceptions (Vroom, 1964).

In short, quality of working life requires that employees are not only satisfied with their jobs but also proficient in them as well, at least at the level to which they aspire. This means that work organizations seeking to ensure a high quality of working life must see to it that their employees are able to become really proficient in their jobs. They must select, train, motivate, and inform employees appropriately, so that the latter are at least in a position to do their jobs really well; i.e., organizations must create optimum conditions for effective performance, even though individual employees may fail to take full opportunity of such conditions and hence may not perform as well as they can.

\section{Social responsibility}

Two final criterion in terms of which to judge the quality of working life is one that has only really become significant over the past decade. It is the degree to which the employing organization is perceived by its members to be involved in activities that are felt to be socially beneficial. Over the past decade, the public have become increasingly concerned about the consequences of actions taken by work organizations on the quality of life-in-general. As a consequence, work organizations whose actions are seen to have beneficial consequences receive more acclaim and are accorded more prestige than those whose actions are felt to have injurious or harmful consequences.

The importance of this aspect of organizational life derives from the fact that employees who feel their organization is acting in a socially responsible manner, in terms of such things as its products, services, marketing techniques, waste products, environmental protection, employment practices, and stance on political issues, will tend to value their work and careers more highly as a result, which in turn is likely to enhance their self-esteem and well-being (Terkel, 1974; Rosow, 1974); Conversely, organizations which are seen to be acting in a socially irresponsible manner in these respects will cause increasing numbers of their members to depreciate the value of their work and careers, with negative consequences for their self-esteem and well-being (O'Toole, 1973; Wilson, 1973). What this means for the individual work organization set on improving the quality of life of its members is that it must ensure that its various actions are seen by its own members to be socially responsible in the broadest sense. To do this requires that the work organization at least know what actions its 
various members regard as socially responsible and irresponsible, in terms of their conceptions of what constitutes quality of life-in-general.

\section{Criteria of quality: Personal aspects}

It is a difficult task to pull together the various criteria that have been proposed for assessing quality of working life.

For one thing, there is disagreement as to the precise ways in which each of the various criteria themselves should best be understood. For another, the various criteria are themselves multidimensional and value-laden, in that they contain several overlapping features and their definition as valuable ends in themselves is partly, and inevitably, a function of subjective preferences. Despite these problems, it can safely be argued that the ultimate aim of the various steps taken to improve the quality of working life is to enhance the 'positive growth' of job incumbents. In an important sense, the criteria that define successful growth of this kind thus constitute the optimum way of gauging the success or failure of any attempt to improve the quality of working life. Put another way, a work organization which satisfies each of the eight sets of criteria mentioned earlier should have employees characterized by the following features, which collectively define what is meant by psychological growth or mental health. Thus, while the criteria listed so far are the result of looking at the problem of quality of working life from the perspective of the work organization, the following criteria indicate the characteristics individuals should ideally possess if their working life is of optimum quality.

- $\quad$ Knowledge: The continuing acquisition of knowledge is usually regarded as essential for psychological growth. Growth comes from exposure to unfamiliar and novel experiences, in the work situation and beyond, which are absorbed into the fabric of an individual's personality.

- Integration: Psychological growth is not only dependent on adding to what one knows, but also upon an individual integrating what he has learnt with what he already knows or believes. It is clearly insufficient for an individual merely to accumulate knowledge in a disconnected or irrelevant manner. For genuine growth to occur, most individuals must relate what one learns from, say, ones job to ones past experiences, in such a way that the capacity to benefit from future experiences is enhanced or enriched. 
- Creativity: The third essential characteristic of genuine psychological growth is the provision of something new or novel, at least for the person concerned. It is important that the acquisition and absorbing of knowledge be done in such a way that it leads to creativity, in the sense of the person possessing something different from what he did earlier. That which is 'created' in this way need not, and rarely is, something of significance or importance for mankind in general; the important things are merely that the process leads to the creation of something novel or new to the individual, and originates from within the person himself.

- $\quad$ Environmental mastery: Psychological growth requires that people are able 'to live with insecurity, to accept change and alteration and be able to deal with complexity' (Herzberg, 1966, p. 59). This implies that individuals are accepting of what they cannot change or alter to suit themselves, yet capable of altering or changing some things, at least to an acceptable degree. In this latter respect, what is important is that people feel they are reasonably successful in a number of different spheres - interpersonal relations, problem-solving, work, sport and so forth; that they achieve at least some of their goals in areas that are important to them.

- Individuation: It is generally agreed that psychological growth, being a species of biological growth, proceeds from something like an undifferentiated mass to separate kinds of experiences and behaviours. A distinctive feature of these latter behaviours and experiences is that if they are to lead to genuine psychological growth, they must result in a personality which is independent in the fullest sense; i.e., one which is able to resist environmental influences whenever this is felt to be really necessary and is able to 'steer itself' instead of merely responding to external pressures.

- Harmony: For growth to occur, individuals must come to possess some kind of relatedness or balance within themselves. They must, in other worlds, be able to reconcile the various internal and external pressures made on their 'inner selves'. The achievement of such a state of inner balance or internal relatedness is critical for growth, whether it is described psychoanalytically as the integration of the ego and the id, or, in more orthodox terms, as the successful resolution of mental conflicts.

- Reality: Unless individuals are able to perceive reality reasonably accurately, they are not going to develop those critical states which define psychological well-being. There are two aspects of this accurate apprehension of the world within which people live out 
their lives that are important here. First, individuals should not allow their perception of events to be unduly influenced by their personal emotions, feelings and motives. Second, they should develop a deep-seated concern and sympathy with others recognizing that their experiences are worthy of attention and interest and that their perceptions need to be taken into account.

- $\quad$ Self-actualization: This final feature of psychological growth, one stressed by a variety of writers, including May (1967), Rogers (1961), Maslow (1959), Jahoda (1955) and Herzberg (1966), in some ways describe a feature that is common to all the others. It is that growth must involve a progression or development in which we realize our potential to ever increasing degrees. All these writers stress that psychological wellbeing requires that we want to be more than we are at present, or to achieve more than we do at present. For instance, Maslow (1959) emphasizes that we all have a potential for being more than we are at the moment, and that the realization of this potential through actions and relations is a prime aspect of health. In a similar vein, Jahoda (1955) stresses that a strong investment-in-living represents positive health and is necessary for self-actualization. Finally, Herzberg (1966) argues that self-actualization is a process in which the individual becomes more truly himself through realizing his potentialities as a full human being to a greater extent than before.

In summary, quality of working life is defined by the two sets of criteria that have been proposed; the one set dealing with the characteristics of the work situation, which will result in an optimum quality of working life for employees; the other referring to the set of characteristics employees should ideally possess if they have been exposed to a work situation with these characteristics.

\section{IMPORTANT QUALIFICATIONS}

However, there are at least three important cautionary remarks that need to be added to this conclusion. First, regardless of how one approaches the issue of quality of working life, it is important to recognize that there are large individual differences in preferences regarding the criteria that have been proposed. Specifically, largely as a result of exposure to different sub-cultural norms and values, people differ in their definitions of what constitutes a high quality of working life. It is thus necessary for work organizations to accommodate these sorts 
of different preferences, by making the necessary adaptations and adjustments to the criteria indicated in this article. There are a number of ways this can be done, of which the following appear most immediately obvious.

Within particular work groups, diversity can be achieved by tailoring individual work assignments to fit individual preferences. In addition, within work organizations, it is possible to allow for diversity by designing jobs differently from one work unit to the next, perhaps even permitting employees to select the pattern of work they prefer most. Finally, diversity among work organizations can be attained by giving the various organizations latitude to develop their own unique ways of allocating duties and responsibilities among their members. In those ways employees will be encouraged to exercise a free and informed choice that takes into account some of the more subtle aspects of the criteria for quality of working life we have discussed.

Second, there are complex relations between the various criteria of quality of working life. Specifically, some of the criteria are likely to be positively correlated, while others are likely to be negatively correlated, in the sense that the attainment of one criteria will make the attainment of others easier to achieve, while impairing or making the attainment of others more difficult. For instance, the provision of challenging and interesting work is likely to raise employee job satisfaction as well as to improve their chances for personal growth. Conversely, heavy emphasis on the rule of law in work organizations may promote impersonality and make it more difficult to develop effective human relations in some cases. Again, the high involvement of employees which results from the provision of interesting and challenging jobs may make it more difficult for employees to achieve the right kind of balance between their working and non-working lives. In short, there appears to be inherent trade-off relationships among some of the criteria of quality of working life, which may require a decline in one quality in order to improve another.

Third, there are a number of forces operating to affect the importance employees attach to the various criteria of quality of working life over time. Such long-term changes may have the result of altering the sort of relations that exist between the different criteria. Certainly, the trade-off relations that exist among the various criteria are not immutably set, but may alter drastically over time. Whatever the changes that occur, they appear to be mainly the result of two interesting forces.

First, as a consequence of rising standards of living and education, employees are increasingly demanding a higher quality of working life, one characterized by the greater 
provision of the various criteria discussed in this article. Second, the public media have increasingly drawn attention to the plight of specific groups of employees, increasing their awareness of deficiencies in their work situations and putting pressure on work organizations to improve the quality of working life of those employees; e.g., Blacks in South Africa in the 1970 's, Negroes in America in the 1950's and Women in the 1960's.

As a final point, it should be borne in mind that there is an absence of empirical research dealing with most of the issues raised in this paper. What is needed urgently if managers are to improve the quality of working life of their employees really effectively, is more research into such questions as the relations between each of the criteria, the kinds of changes that occur in employee perceptions of these criteria over time, and how a change in one criterion in fact affects other criteria. It is my hope that the present article will provide an impetus for such research, besides making clearer the way in which the term 'quality of working life' is understood by most industrial psychologists at present.

\begin{abstract}
In this paper an attempt is made to clarify precisely what industrial psychologists understand by the widely-used term, quality of working life. A number of 'situational' criteria are proposed in terms of which to gauge the quality of working life in a given organization. These criteria are discussed under the following headings: adequate compensation, working conditions, human relations, work and leisure, effective performance, and social responsibility. For optimum quality of working life, the provision of a work situation that meets these criteria should 'result' in employees characterized by a state of psychological well-being as regards their work. A number of 'personal' criteria are proposed to judge well-being. These are discussed under the following headings: knowledge, integration, creativity, individualization, harmony, reality and self-actualization. Throughout the paper attention is directed at what work organizations should do in order to satisfy those situational and personal criteria that collectively define quality of working life.
\end{abstract}

\title{
REFERENCES
}

Argyris, C. Integrating the Individual and the Organization. New York: Wiley, 1964. Barron, F. Creativity and Psychological Health. Princeton, N.J.: Nostrand, 1963.

Bell, C.R. Men at Work. London: Allen \& Unwin, 1974.

Bennis, W. Changing Organizations. New York: McGraw-Hill, 1966.

Birchall, D., \& Wild, R. Job restructuring among blue-collar workers. Personnel Review, 1973, 2, 40-55. 
Carlson, R.E. Degree of job fit as a moderator of the relationship between job performance and job satisfaction. Personnel Psychology, 1969, 22, 159-170.

Davis, L.E. The design of jobs. Industrial Relations, 1967, 6, 21-45.

Dunnette, M.D. Towards fusion. In M.D. Dunnette (Ed.), Handbook of Industrial and Organizational Psychology. Chicago: Rand-McNally, 1976, 1-12.

Festinger, L. A theory of social comparison processes. Human Relations, 1954, 7, 117-140.

Friedman, G. The Anatomy of Work. New York: Free Press, 1961.

Hampden-Turner, C. Radical Man. New York: Duckworth, 1971.

Herman, J.B. Are situational contingencies limiting the job attitude - job performance relationship. Organizational Behavior \& Human Performance, 1973, 10, 208-224.

Herzberg, F. Work and the Nature of Man. Cleveland, Ohio: World Publishing Company, 1966.

Herzberg, F. Mausner, B., \& Snyderman, B. The Motivation to Work. New York: Wiley, 1959.

Hill, P. Towards a New Philosophy of Management. London: Gower Press, 1971.

Jahoda, M. Current Concepts of Mental Health. New York: Basic Books, 1955.

Katzell, R.A. Personal values, job satisfaction, and job behaviour. In H. Borow (Ed.), Man in a world of work. Boston, Mass.: Houghton Mifflin, 1964, 341-363.

Kornhauser, A.W. Mental Health of the Industrial Worker. New York: Wiley, 1965.

Lawler, E.E. Pay and Organizational Effectiveness: A Psychological Analysis. New York: McGraw-Hill, 1971.

Likert, R. New Patterns of Management. New York: McGraw-Hill, 1951.

Locke, E.A. Relation of task success to task liking and job satisfaction. Journal of Applied Psychology, 1968, 49, 319-385.

Locke, E.A. What is job satisfaction? Organizational Behaviour \& Human Performance, 1969, 4, 309-336.

Locke, E.A. The nature and causes of job satisfaction. In M.D. Dunnette (Ed.) Handbook of Industrial and Organizational Psychology. Chicago: Rand-McNally, 1976, 1297-1349.

Lofquist, L.H., \& Davis, R.V. Adjustment to Work. New York: Appleton Century-Crofts, 1969.

May, R. Psychology and the Human Dilemma. Princeton, N.J.: Van Nostrand, 1967.

Maslow, A.H. Motivation and Personality. New York: Harper \& Row, 1959.

Opsahl, R.L., \& Dunnette, M.D. The role of financial compensation in industrial motivation. Psychological Bulletin, 1966, 66, 94-118.

Orpen, C. Productivity and Black Workers in South Africa: A Psychological Analysis. Cape Town: Juta, 1976.

O'Toole, P. Work in America. Cambridge, Mass.: Massachusetts Institute of Technology Press, 1973.

Paul, W. \& Robertson, K. Job Enrichment and Employee Motivation. London: Gower Press, 1970.

Porter, L.W., \& Lawler, E.E. Managerial Attitudes and Performance. Homewood, Ill.: Irwin, 1968.

Rogers, C. On Becoming a Person. Boston, Mass.: Houghton Mifflin, 1961.

Rosow, J. The Worker and the Job. Englewood-Cliffs, N.J.: Prentice-Hall, 1974.

Salaman, G. Community and Occupation. London: Cambridge University Press, 1974.

Shephard, J .M. Functional specialization and work attitudes. Industrial Relations, 1969, 8, 185-194.

Sofer, C. The Organization from Within. London: Tavistock, 1961.

Sofer, C. Men in Mid-career. London: Cambridge University Press, 1970.

Terkel, S. Working. New York: Random House, 1974. 
Vroom, V.H. Work and Motivation. New York: Wiley, 1964.

Wall, T.D. The Perceived Determinants of Job Satisfaction and Job Dissatisfaction in a Chemical Firm. Unpublished doctoral thesis, University of Nottingham, England, 1971.

Walker, C.R. \& Guest, R.H. The Man on the Assembly Line. Cambridge, Mass.: Harvard University Press, 1962.

Wicker, A.W. Attitudes versus action: The relationship of verbal and overt behavioral responses to attitude objects. Journal of Social Issues. 1969, 25, 41-78.

Wilson, N.A.B. On the quality of working life. Department of Employment: Manpower paper, No.7, Her Majesty's Stationary Office, London, 1973. 